\title{
LAS RESISTENCIAS DE LA MEMORIA O CERO EN CONDUCTA
}

\section{Por Paula Marcela Trujillo J.}

\author{
Profesora Auxiliar \\ Escuela de Comunicación Social \\ Facultad de Artes Integradas \\ Universidad del Valle \\ Cali, Colombia \\ pavitas@hotmail.com
}

RESUMEN: Este texto intenta dar cuenta de dos aspectos: primero, la manera como un sujeto creador -en la ocasión el realizador de cine Carlos Mayolo- establece relaciones con su entorno, a través de películas, que se convierten entonces en forma de resistencia; segundo, cómo esa obra y su autor testimonian el carácter implacable del paso del tiempo.

PALABRAS CLAVE: Carlos Mayolo, Cine colombiano, Caliwood 


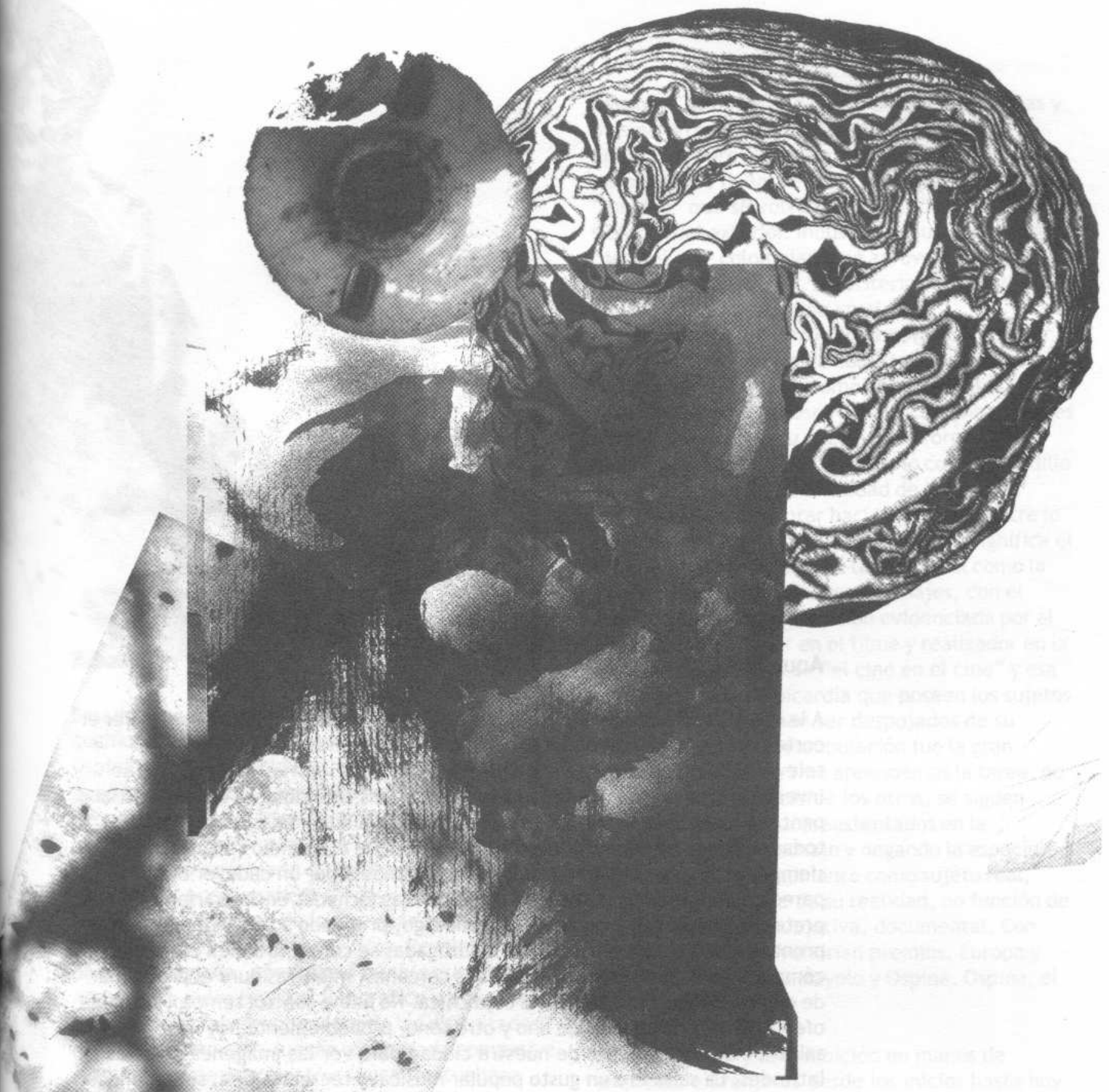

El presente texto no pretende un abordaje íntimo de la personalidad del realizador Carlos Mayolo, ni tan siquiera una mirada exhaustiva y rigurosa a su obra. No es tampoco un homenaje que sólo lo harán los "buenos pocos amigos". El presente texto intenta dar cuenta de la manera como un sujeto creador establece relaciones con su entorno, a través de películas, que se convierten en formas de resistencia, y cómo un observador se topa con una obra y con un personaje que nos recuerda el paso del tiempo: implacable. Hoy, ya reconocida la trayectoria de nuestro antihéroe en cuestión, la tarea se vuelve más compleja pero por demás un bello desafío. 
AQUEL 19

A la edad de 15 años, estando en el bachillerato, tuve la oportunidad de ver el cortometraje Aquel 19 en un espacio que se denominaba "Cine en televisión". Espacio que se constituyó en una de las mil estrategias que se inventó Focine para darle salida a cortometrajes colombianos a través de la pantalla tonta, aún tonta. En su momento evadía una adolescencia, como todas, cargada de rebeldía y confusión, en la que el suicidio se acariciaba siempre como posibilidad. Los que no decidimos tener un cadáver bien parecido pensábamos después que con las trasnochadas encontraríamos el pretexto para dar el gran paso. Sin embargo, probando a tener que asumirse pronto en adulto, las noches y las madrugadas se convertirian en el espacio cómplice de encontrarse con imágenes cercanas, mientras duró el programa de exhibir películas mediante la caja chica. No había control remoto, no había oferta diversa de canales de uno y otro tono, probablemente hoy nos saltaríamos las imágenes de nuestra ciudad para ver las imágenes de otras latitudes. La salsa era un gusto popular musical y recrear a Cali, sin reconocer aún la ciudad, era de todas maneras un atractivo visual de descubrimiento. Además la historia de jovencitos parecía querer decirle cosas a mi generación, que se confrontaba con papás "autoritarios" y que por lo demás soñaba con el amor verdadero. El corto sigue diciendo cosas, visto con diferentes públicos. Aquel 19 nos obliga a pensar la ciudad, nos hace revisar nuestra condición de caleños. Las imágenes del Cali del ayer (años setenta) sugiere rasgos de identidad que, aunque no todos los caleños compartan, hoy hacen parte del carácter cultural patrimonio nuestro: Pance, el fútbol, el Deportivo Cali, el equipo América, las rumbas, la música dura salsa, bailar guateque, el amor a los veinte años, un poco antes. Aquel 19 tiene la facultad de dejarnos ver una época de la ciudad, un momento suspendido en la historia. El arte del olvido con el cine es imposible. Las resistencias de la memoria quedan materializadas en cuadros en movimiento, a la luz de un lienzo en blanco que siempre da visos de colores, algunos grises, en los años ochentas con "esa maldita disciplina que es bailar en Cali" a todo timbal y morir. 
después Carlos Mayolo, soñaron con estrategias y plasmaron en imágenes los años del cine en Colombia, pero sus iniciativas sucumbieron ante las presiones financieras de un descubrimiento "mágico" que se volvía industria, por presión siempre del exterior. Industria pequeña que, en el caso del cine colombiano, se aprovechaba de lo comercial para existir, sin criterios de estética cinematográfica del cine en el cine, autoconsciente. Agarrando pueblo va a develar, entonces, la dinámica de cómo los documentales construyen la verdad y cómo el documental debe restituir de manera respetuosa y cercana lo que es lo real. Ospina con su experiencia formativa cinematográfica en UCLA y Mayolo con su mundillo de excesos y de intelectualidad de izquierda parecían querer apuntar hacia un híbrido entre lo que significa filmar la realidad y lo que significa el tener que poner en escena tanto lo real como la ficción. Este juego con los personajes, con el formato, la desdramatización evidenciada por el autor que es director en el filme y realizador en la realidad, este juego de "el cine en el cine" y esa idea de dignidad y picardía que poseen los sujetos filmados que no deben ser despojados de su fuerza mediante la manipulación fue la gran "lección" del filme. Y no aprendemos la tarea, no aprendemos del oficio de los otros, se siguen haciendo documentales sustentados en la explotación del personaje y negando la especial condición del testimoniante como sujeto real, participe y pensante de su realidad, en función de la obra expresiva, subjetiva, documental. Con Agarrando pueblo vendrían premios, Europa y reconocimiento para Mayolo y Ospina. Ospina, el siempre amigo.

películas que, aprovechándose de las dificultades del "tercer mundo", juegan a la mirada compasiva y superficial de sólo mostrar sin contextualizar. Habría que decir que el cine llegó a Colombia poco tiempo después de la famosa proyección en Francia de los hermanos Lumière. Las proyecciones a este lado del mapa datan desde 1897 y eran aún rudimentarias y basadas en el evento en movimiento de la cotidianidad. El nuevo artefacto, el nuevo espectáculo, aparecía también en estos países como un divertimento de feria, aún no había nacido el cine como arte. Bajo el sino de una fuerte inversión extranjera en materia de distribución y exhibición cinematográfica y sin una política estatal de apoyo legislativo y de proyección cultural, la producción fílmica en Colombia va a ser siempre escasa. Los hermanos Di Domenico, los hermanos Acevedo y un poco

La distribución y la exhibición en manos de empresas extranjeras desde los inicios hasta hoy han hecho que la vitrina del cine colombiano no sean nuestras pantallas sino las de los festivales. Focine, Cine en televisión, el Sobreprecio, intentos de plantear fórmulas y políticas de apoyo y de financiación al cine, que dieron sus frutos, pero con tantos tropiezos que terminaron por ser tanteos abandonados. Iniciativas que hoy tienen a Mayolo dedicado a escribir y no a ese trabajo que conoce tan bien: poner la cámara y dirigir los actores. Una imagen es para Mayolo el lugar desde el que se filma con fuerza. El rodaje es para este director, al igual que lo era para Hitchcock, el escenario de la creación, el montaje es sólo la mecánica de armado. El rodaje centra toda la potencia expresiva de la historia y los personajes. 
"Yo sólo sé que vi todo con estos ojos que se van a comer los gusanos". La violencia de los años cincuenta en Cali, el nacimiento del televisor, la explosión del 7 de agosto de 1956, las composiciones y descomposiciones familiares de las casas acomodadas, el amor femenino en todas sus fases y variaciones. Dicho lo indecible. Todas son imágenes mayolescas, como si se las debieran comer los bichos. Dicho lo indecible, acompañado del sonar de un violonchelo desvencijado, el traquetear de la madera y una canción de cuna macabra, he ahí una estética. ¿Cuál estética?, debiéramos preguntarnos. La estética del amor verdadero, en el que se entrega la vida y se juega a la muerte. No son sólo vampiros, son jóvenes con destinitos fatales, trazados sin piedad por el titiritero implacable, que cobra venganza de su suerte. ¿Por qué tantas resistencias? ¿Por qué era necesario nombrar lo innombrable, filmar lo infilmable, decir lo indecible? Mayolo en sus actuaciones y en sus películas intenta encarnar esos seres que se exceden, sin límites. Su personalidad misma refleja ese desacuerdo con el mundo en orden, que establece una sola línea y que le teme a lo realmente real. Esos mundos fantásticos nos hablan más de nosotros mismos que lo que vemos en la TV. Incluso cuando Mayolo hizo televisión, su propuesta era ésa: desvertebrar los referentes de clase, de amor, de narración, de puesta en escena. Es ahí en la historia, en los personajes y en el emplazamiento de cámara que todo cambió. "Yo tenía mi historia muy armada en mi cabeza de una forma evocativa (...). El método de no saber nada y no poder explicar algo".

\section{la mansión de araucaima}

"Siempre la sensación y no la razón". Esa constante entre el exterior del mundo real y el interior de un submundo intersticial, desenfrenado va a ser La Mansión... Una dulce y bella jovencita llega a una gran casa suspendida en el tiempo y provoca en todos los personajes pasiones y sensaciones de piel. Con cada personaje y con cada nueva pasión, los ánimos se alteran, la paz de la casa se agita y ya nada volverá a ser como antes. El piloto, el cura, el guardián, la matrona, el negro, todos se desviven por Angela. El tropicalismo mágico cobra su fuerza y asi como en los anteriores desenlaces la fatalidad llegará con el desenlace anunciado. Con La Mansión... Mayolo consolidará su línea que él denomina como to "gótico-tropical", labor de constructor visual de atmósferas y personajes desencantados. La diferencia entre la estética del exceso, de las pasiones y de la sinceridad que el filme revela, plantea para Mayolo, una diferencia sustancial sobre lo que significa hacer en televisión cosas raras sin justificación formal. El límite, la locura, brotan de la naturaleza de los personajes puestos a jugar en un ambiente que les enrarece la existencia. No estamos ante el efecto visual y el deslumbre técnico, Mayolo ha sabido escoger un tono para cada personaje, para cada escena, para cada diálogo. La televisión no sabe de tono, no sabe de distancias entre cámara y personaje. A la televisión se le escapa la estilización de la luz. No se puede hacer surrealismo y venderlo para la caja mágica. ¿Qué televisión nos mereceremos en este tiempo, en el que la transparencia de la imagen que todo lo registra lo envilece todo? Mayolo ha sabido consagrar en el cine algunos de sus fantasmas, quién sabe si sus miedos sí han quedado plasmados. ¡Habría que decir que su estética, sí!

"Ahora pienso que no le hubiera tenido tanto miedo a la muerte si hubiéramos podido llorar juntos". Cero en conducta o pensar imágenes para resistirse al olvido y restituir la memoria, eso es la obra de Carlos Mayolo. Nacido en Cali en 1945, cuando una guerra dejaba sus sombrías huellas y cuando a los cuarenta con Aquel 19 me hizo pensar en lo que significa una ciudad registrada, ya imborrable. 


\section{EL ESPECTADOR}

"Al salir del teatro, Ricardo González experimentó una apremiante necesidad de volver a ver la cinta. $Y$ asi lo hizo. Se colocó otra vez frente a las mismas secuencias en blanco y negro, siguiendo paso a paso las operaciones de los bandidos, huyendo de la policía (...) Ricardo González sabía que los demás espectadores no conocían el desenlace, y deseó hablar con alguien acerca de ello (...) Pero Ricardo González no tenía a nadie conocido: todas eran personas extrañas, diferentes (...) Apareció la palabrita "fin" y Ricardo comprendió que la película no habia gustado (...) Era una lata, decían, el final era incomprensible. Ricardo caminó por la ciudad durante horas, extrañado ante la reacción de los espectadores. Dudó acerca de la calidad de la película: se pregunto si el equivocado no sería él. ¡Pero qué tenía de raro el final, si todo era muy claro! (...) ¿Qué era lo que la gente no había entendido? Bueno, el no sabía nada de cine como para asegurar tener la razón, de allí el motivo de sus dudas. Si pudiera conversar con alguno (...) Lo mejor que pudo encontrar fue volver al teatro al día siguiente. Al entregar la boleta, el portero lo miró entre sonrisas, reconociéndolo. - Por lo menos a una persona le ha gustado ese hueso de película -dijo a espaldas de Ricardo. Ese tipo que acaba de entrar ya la ha visto como ocho veces (...) En la escena final, cuando Steiger, y la muchacha dicen a la policía: "si, ya bajamos" desde la montaña, Ricardo comprendió una vez más que el público iba a salir sin comprender. ¡Se matan, se tiran de la montaña!- gritó de pronto, parándose de su butaca y usando las manos como parlante (...) - ¡Miren que la cámara enfoca desde abajo, ellos prefieren suicidarse antes que entregarse a la policía, comprendan! (...) - Lo único bueno de esta estafa fue el tipo que se puso a gritar en la mitad de la sala -comentaba después una señora de vestido morado, franqueando la salida (...)”. El Espectador (1969), Andrés Caicedo.

"Pero dejemos quietos a los amigos idos, a los amigos muertos. Lo único cierto, es que nosotros seguimos aquí todavía". Así que no se quede deambulando solito, como un loquito por las calles de Cali, como Ricardito González, porque nadie quiere hablar de cine... Cali es cinegética, como dice Mayolo, y su música es siempre extradiegética.

¡Qué viva el cine! ?

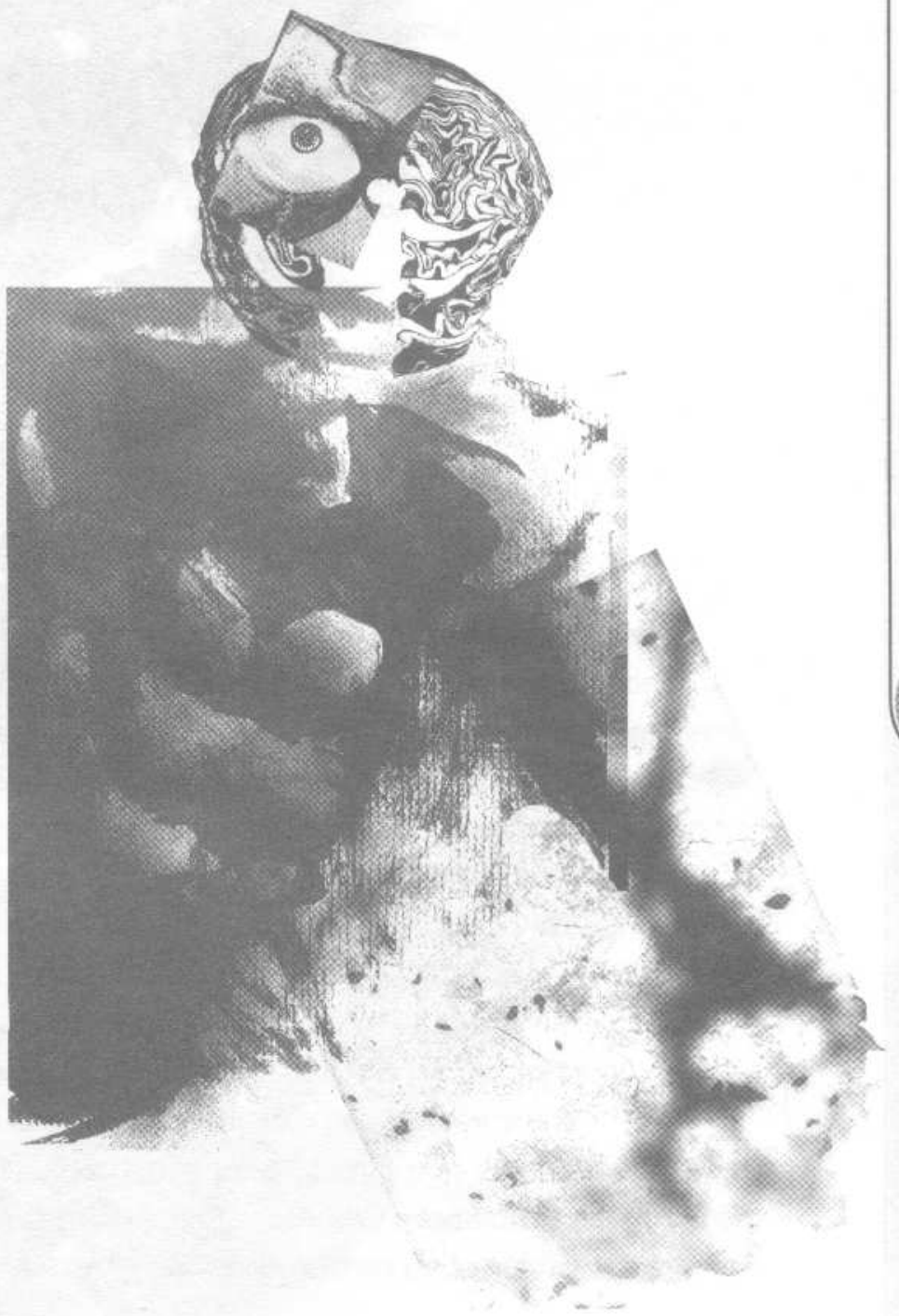

